\title{
Proposal of Intrasporangium mesophilum sp. nov., and reclassification of Humihabitans oryzae Kageyama et al. 2007 as Intrasporangium oryzae comb. nov.
}

\author{
Correspondence \\ Xing-Hong Wang \\ wangxh@ynu.edu.cn \\ Wen-Jun Li \\ wjli@ynu.edu.cn
}

\author{
Ling-Ling Yang, ${ }^{1} \dagger$ Tao Ao, ${ }^{1} \dagger$ Xing-Hong Wang, ${ }^{1}$ Jie He, ${ }^{1}$ \\ Hans-Peter Klenk, ${ }^{2}$ Shu-Kun Tang ${ }^{1}$ and Wen-Jun $\mathrm{Li}^{1}$ Kunming 650091, PR China D-38124 Braunschweig, Germany \\ ${ }^{1}$ Key Laboratory of Microbial Diversity in Southwest China, Ministry of Education and Laboratory for \\ Conservation and Utilization of Bio-resources, Yunnan Institute of Microbiology, Yunnan University, \\ ${ }^{2}$ DSMZ-Deutsche Sammlung von Mikroorganismen und Zellkulturen GmbH, Inhoffenstraße 7b,
}

\begin{abstract}
A Gram-positive and aerobic bacterium, designated strain YIM $49065^{\top}$, was isolated from rhizospheric soil of Jatropha curcas in Yunnan, China. This isolate formed branched and fragmented mycelia containing LL-diaminopimelic acid as the diagnostic diamino acid in the cell-wall peptidoglycan. The major cellular fatty acid profile was characterized by iso- $C_{14: 0}$, iso- $C_{15: 0}$ and iso- $\mathrm{C}_{16: 0}$, and the predominant menaquinone was $\mathrm{MK}-8\left(\mathrm{H}_{4}\right)$. The DNA $\mathrm{G}+\mathrm{C}$ content was $69.6 \mathrm{~mol} \%$. A phylogenetic analysis based on 16S rRNA gene sequence demonstrated that strain YIM $49065^{\top}$ was closely associated with Intrasporangium calvum DSM $43043^{\top}$ and Humihabitans oryzae KV-657 ${ }^{\top}$, exhibiting $98.8 \%$ and $98.6 \% 16 \mathrm{~S}$ rRNA gene sequence similarities, respectively. Furthermore, DNA-DNA hybridizations among strains YIM 49065 ${ }^{\top}$, I. calvum DSM 43043 ${ }^{\top}$ and $H$. oryzae DSM $22331^{\top}$ indicated that this isolate represented a novel species in the genus Intrasporangium. On the basis of these data, we proposed one novel species, Intrasporangium

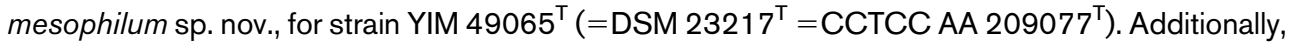
the comparison of biochemical and phylogenetic characters supported the reclassification of Humihabitans oryzae as a separate species within the genus Intrasporangium, Intrasporangium oryzae comb. nov. (type strain $\mathrm{KV}-657^{\top}=\mathrm{JCM} 15924^{\top}=\mathrm{NBRC} 101802^{\top}=\mathrm{NRRL} \mathrm{B}-24470^{\top}$ ).
\end{abstract}

During a screening programme of bacteria with lipase activity used for biodiesel production, strain YIM $49065^{\mathrm{T}}$ was isolated from the rhizospheric soil sample of an oil-seed plant, Jatropha curcas, collected from Chuxiong, Yunnan province, south-west China. The isolate was obtained after incubation at $28{ }^{\circ} \mathrm{C}$ for 14 days and was subsequently maintained on trypticase soy agar (TSA; Difco) at $4{ }^{\circ} \mathrm{C}$, and as a glycerol suspension $(20 \%, \mathrm{v} / \mathrm{v})$ at $-20{ }^{\circ} \mathrm{C}$. To determine the taxonomic position of this isolate, a preliminary sequence analysis based on the 16S rRNA gene was performed. Genomic DNA extraction and PCR amplification of the 16S rRNA gene were carried out by using the method described by Li et al. (2007). Sequence comparison via BLAST searches (Altschul et al., 1990) against

†These authors contributed equally to this work.

The GenBank/EMBL/DDBJ accession number for the 16S rRNA gene sequence of strain YIM $49065^{\top}$ is $\mathrm{HQ20} 4221$.

Two supplementary tables and five figures are available with the online version of this paper. sequences from the GenBank, EMBL or DDBJ databases revealed that strain YIM $49065^{\mathrm{T}}$ had a close relationship with members of the family Intrasporangiaceae, especially the genera Intrasporangium (Kalakoutskii et al., 1967) and Humihabitans (Kageyama et al., 2007), both being monospecific. At the time of writing, the family Intrasporangiaceae (Stackebrandt et al., 1997; Stackebrandt \& Schumann, 2006; Zhi et al., 2009) contains 19 genera with validly published names, including Intrasporangium as the type genus. The genus Humihabitans was proposed mainly according to differences of menaquinone and fatty acid types from its closest phylogenetic neighbour Intrasporangium (Kageyama et al., 2007).

In order to discriminate these micro-organisms and identify strain YIM $49065^{\mathrm{T}}$, a polyphasic approach was used. Cultural characteristics and colour of the aerial and substrate mycelia were determined following the method described by Shirling \& Gottlieb (1966). Morphological characteristics were observed by using light microscopy (BH2; Olympus) and scanning electron microscopy (JSM5600LV; JEOL) after 
14 days' growth on ISP (International Streptomyces Project) 2 agar medium (Shirling \& Gottlieb, 1966). Growth at various temperatures $\left(4,10,20,28,32,37,40\right.$ and $\left.45^{\circ} \mathrm{C}\right)$, $\mathrm{pH}(5,6,7,8,9$ and 10$)$ and $\mathrm{NaCl}$ concentrations $(0-10 \%$, $\mathrm{w} / \mathrm{v}$, at intervals of $0.5 \%$ ) were performed using ISP 2 as basal medium. Cells of the strain were Gram-positive as determined according to Gregersen's method (Gregersen, 1978). Strain YIM $49065^{\mathrm{T}}$ developed well on most test media, including ISP 2, ISP 3, ISP 5 (Shirling \& Gottlieb, 1966), potato-glucose agar, nutrient agar and Czapek's agar (Dong \& Cai, 2001), but weakly on ISP 4 (Shirling \& Gottlieb, 1966). White to pale orange-yellow substrate mycelia and white aerial mycelia were produced. Strain YIM $49065^{\mathrm{T}}$ formed extensively branched and fragmented mycelia (Fig. S1, available in IJSEM Online). The isolate grew well at $20-37{ }^{\circ} \mathrm{C}$ (optimum $28{ }^{\circ} \mathrm{C}$ ), $\mathrm{pH}$ 6-8 (optimum $\mathrm{pH} 7-8)$ and in the presence of $3 \% \mathrm{NaCl}(\mathrm{w} / \mathrm{v})$. No diffusible pigments were produced on any media tested here.

Physiological and biochemical characteristics were determined following standard procedures. Catalase activity was determined by assessing bubble production in $3 \%(\mathrm{v} / \mathrm{v})$ $\mathrm{H}_{2} \mathrm{O}_{2}$. Degradation of cellulose, gelatin, urea and Tweens 20, 40 and 80 was determined as described by Cowan \& Steel (1965). Carbon utilization was tested using ISP 9 (Pridham \& Gottlieb, 1948) containing each carbon source at a final concentration of $0.5 \%(\mathrm{w} / \mathrm{v})$. Other physiological characteristics, such as $\mathrm{H}_{2} \mathrm{~S}$ and melanin production, and milk coagulation and peptonization, were examined according to the protocols described by Gordon et al. (1974). These phenotypic characteristics are listed in the species description and Table 1. Strain YIM $49065^{\mathrm{T}}$ exhibited many phenotypic features in common with the type strains of Intrasporangium calvum and Humihabitans oryzae. They all grew with $3 \% \mathrm{NaCl}$ and were positive for catalase activity, nitrate reduction and utilization of fructose, sucrose and Dxylose as sole carbon sources, but negative for production of $\mathrm{H}_{2} \mathrm{~S}$, hydrolysis of urea and utilization of arabinose and lactose. Some characteristics differentiating strain YIM $49065^{\mathrm{T}}$ from the type strains of I. calvum and H. oryzae are given in Table 1.

Biomass for the study of chemotaxonomic characteristics, except cellular fatty acid analysis, was prepared by cultivation in shaken flasks of tryptic soy broth (TSB; Difco) at 170 r.p.m. at $28{ }^{\circ} \mathrm{C}$ and then harvested by centrifugation. Isomers of diaminopimelic acid were analysed according to the procedure developed by Hasegawa et al. (1983). Whole cell sugars were detected by precolumn derivatization with 1phenyl-3-methyl-5-pyrazolone (PMP) by HPLC (Tang et al., 2009). Polar lipids were extracted and identified by two-dimensional TLC (Minnikin et al., 1979; Collins \& Jones, 1980). Menaquinones were extracted and purified as described by Minnikin et al. (1984) and analysed by HPLC (Kroppenstedt, 1982) with Pseudonocardia antarctica DSM $44749^{\mathrm{T}}$ [predominant menaquinone is $\mathrm{MK}-8\left(\mathrm{H}_{4}\right)$ ] and Bacillus psychrodurans DSM $11713^{\mathrm{T}}$ (predominant menaquinones are MK-8 and MK-7) as reference strains. For fatty acid analysis, strain YIM $49065^{\mathrm{T}}$ was prepared by scraping cells from TSA that had been incubated for 5 days at $28{ }^{\circ} \mathrm{C}$. I. calvum DSM $43043^{\mathrm{T}}$ and H. oryzae DSM $22331^{\mathrm{T}}$ were also grown under the same conditions until they reached exponential phase. Analysis was carried out by using the Sherlock Microbial Identification System (MIDI) according

Table 1. Characteristics that differentiate strain YIM $49065^{\top}$ from its nearest phylogenetic neighbours

All data were obtained from this study. +, Positive; -, negative.

\begin{tabular}{|c|c|c|c|}
\hline Characteristic & YIM $49065^{\mathrm{T}}$ & I. calvum DSM $43043^{\mathrm{T}}$ & H. oryzae DSM $22331^{\mathrm{T}}$ \\
\hline $\mathrm{pH}$ range & $6-8$ & $6-8$ & $5-11$ \\
\hline Temperature range $\left({ }^{\circ} \mathrm{C}\right)$ & $20-37$ & $20-40$ & $8-40$ \\
\hline Aerial mycelium & White & None & None \\
\hline Substrate mycelium & White, pale orange-yellow & Whitish, cream-whitish & Pale yellow \\
\hline Degradation of gelatin & + & - & - \\
\hline \multicolumn{4}{|l|}{$\begin{array}{l}\text { Utilization as sole carbon } \\
\text { source }\end{array}$} \\
\hline Cellobiose & - & + & - \\
\hline Glucose & + & - & + \\
\hline Inositol & - & - & + \\
\hline Mannitol & - & - & + \\
\hline Raffinose & - & + & - \\
\hline L-Rhamnose & - & + & - \\
\hline D-Ribose & + & - & - \\
\hline Sorbose & - & - & + \\
\hline Trehalose & - & - & + \\
\hline Major fatty acids $(\% ;>10 \%)$ & $\begin{aligned} \text { iso- } \mathrm{C}_{14: 0} & (11.3), \text { iso- } \mathrm{C}_{15: 0}(43.3), \\
& \text { iso- } \mathrm{C}_{16: 0}(13.0)\end{aligned}$ & $\begin{array}{c}\text { iso- } \mathrm{C}_{15: 0} \text { (37.6), iso- } \mathrm{C}_{16: 0} \\
(13.1)\end{array}$ & $\begin{aligned} \text { iso- } \mathrm{C}_{14: 0} & (14.7), \text { iso- } \mathrm{C}_{15: 0}(41.8) \\
& \text { iso- } \mathrm{C}_{16: 0}(18.7)\end{aligned}$ \\
\hline Whole cell-sugars & Galactose, mannose, glucose, arabinose & Galactose, mannose, glucose & Galactose, mannose, glucose, ribose \\
\hline DNA G $+C$ content $(\mathrm{mol} \%)$ & 69.6 & 68.8 & 71.2 \\
\hline
\end{tabular}


to the manufacturer's instructions. Fatty acid methyl esters were then analysed by GC (Agilent Technologies 7890A GC System) by using the Microbial Identification software package (Sherlock Version 6.1; MIDI database TSBA6).

The chemotaxonomic data showed some significant similarities among strains YIM $49065^{\mathrm{T}}$, I. calvum DSM $43043^{\mathrm{T}}$ and $H$. oryzae DSM $22331^{\mathrm{T}}$, even though there was some diversity. The whole cell sugars of strain YIM $49065^{\mathrm{T}}$ were galactose, mannose, arabinose and glucose. The polar lipids of the three strains comprised diphosphatidylglycerol, phosphatidylglycerol, phosphatidylethanolamine, phosphatidylinositol and phosphatidylinositol mannoside, with an unknown ninhydrin-positive phosphoglycolipid and two unknown lipids (Fig. S2). Interestingly, the predominant menaquinone was detected as MK-8 $\left(\mathrm{H}_{4}\right)$ for strains YIM $49065^{\mathrm{T}}$, I. calvum DSM $43043^{\mathrm{T}}$ and H. oryzae DSM $22331^{\mathrm{T}}$ (Fig. S3). This result differs from previous reports that the predominant menaquinone of I. calvum was MK-8 (Collins et al., 1984; Kalakoutskii, 1989; Kageyama et al., 2007). The main reason why $H$. oryzae was proposed as a new genus in the family Intrasporangiaceae was that the predominant menaquinone of $H$. oryzae DSM $22331^{\mathrm{T}}$ was determined as MK- $8\left(\mathrm{H}_{4}\right)$ by Kageyama et al. (2007). Given that all other representatives of the family possess totally MK- $8\left(\mathrm{H}_{4}\right)$ as the characteristic menaquinone (Stackebrandt \& Schumann, 2006; Wang et al., 2009), MK-8( $\left.\mathrm{H}_{4}\right)$ should be the characteristic menaquinone not only of the other members of the genus Intrasporangium, but also of the family Intrasporangiaceae. The cellular fatty acid profile for the novel strain consisted predominantly of branched fatty acids, including ( $>10 \%$ of total fatty acids) iso- $\mathrm{C}_{14: 0}$ $(11.3 \%)$, iso- $\mathrm{C}_{15: 0}(43.3 \%)$ and iso- $\mathrm{C}_{16: 0}(13.0 \%)$. This profile is similar to those of the closely related species $I$. calvum and $H$. oryzae, but there were differences in the proportions of each fatty acid (Table 1). The fatty acid profiles of strains YIM $49065^{\mathrm{T}}$, I. calvum DSM $43043^{\mathrm{T}}$ and H. oryzae DSM $22331^{\mathrm{T}}$ are given in Table S1.

Multiple alignments and sequence evolutionary distance calculations were carried out by using CLUSTAL X software (Thompson et al., 1997), and the positions with gaps were excluded before final analysis. Phylogenetic analyses were performed using the neighbour-joining (Saitou \& Nei, 1987) and maximum-parsimony (Fitch, 1971) methods contained in MEGA version 4 (Tamura et al., 2007). Maximum-likelihood analysis was performed by using PhyML (Guindon \& Gascuel, 2003). The topology of the phylogenetic tree was evaluated by the bootstrap resampling method of Felsenstein (1985) with 1000 replicates. The 16S rRNA gene sequence of strain YIM $49065^{\mathrm{T}}$ shared the highest pairwise similarity with I. calvum DSM $43043^{\mathrm{T}}(98.8 \%)$ and $H$. oryzae $\mathrm{KV}-657^{\mathrm{T}}$ (98.6\%), while I. calvum and H. oryzae exhibited $98.7 \%$ similarity to each other. This result was confirmed by using MEGA version 4 with pairwise deletion for gaps; however, the similarity value between $I$. calvum and $H$. oryzae was reported as $97.6 \%$ by Kageyama et al. (2007), determined with gaps. The phylogenetic tree reconstructed by using the neighbourjoining method suggested that strain YIM $49065^{\mathrm{T}}$ formed a stable clade with I. calvum and H. oryzae, being well separated from the other genera of family Intrasporangiaceae (Fig. 1). This relationship was supported by maximum-parsimony

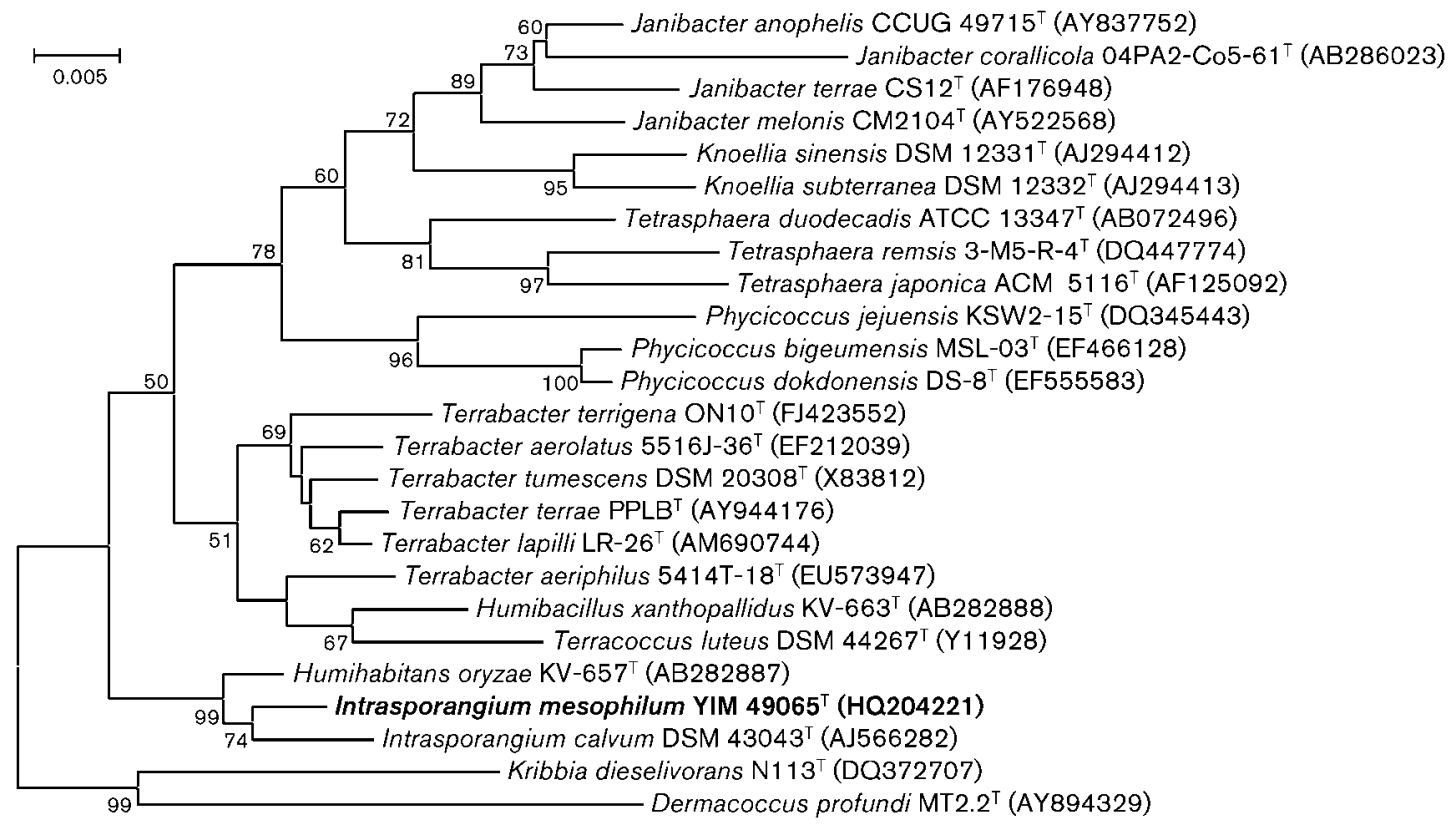

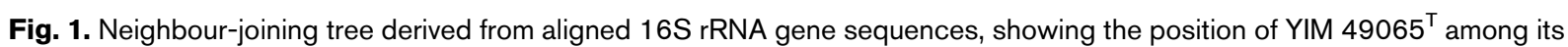
phylogenetically closest neighbours. Bootstrap values (>50\%) based on 1000 replications are shown at branch nodes. Bar, 0.005 substitutions per nucleotide position. 
and maximum-likelihood tree-making algorithms with high bootstrap value (Figs S4 and S5).

The $\mathrm{G}+\mathrm{C}$ content of genomic DNA was determined using the HPLC method as described by Mesbah et al. (1989), with DNA prepared according to the method of Marmur (1961). DNA-DNA hybridization was carried out by using photobiotin-labelled probes in microplate wells with five replications as described by Ezaki et al. (1989) and He et al. (2005). Fluorescence was measured by using a microplate spectrofluorometer (Gemini XPS; Molecular Devices). Reciprocal reactions were performed for every DNA pair. The DNA G + C content of strain YIM $49065^{\mathrm{T}}$ was $69.6 \mathrm{~mol} \%$. The levels of DNA-DNA relatedness between strain YIM $49065^{\mathrm{T}}$ and its nearest neighbours, I. calvum DSM $43043^{\mathrm{T}}$ and H. oryzae DSM $22331^{\mathrm{T}}$, were $43.9 \%$ and $52.1 \%$, respectively (standard deviations were $3.2 \%$ and $5.4 \%$ ). I. calvum and $H$. oryzae shared a value of $40.6 \%$ (standard deviation $7.1 \%$ ). These are lower than the $70 \%$ cut-off point recommended for delineation of a novel species (Stackebrandt \& Goebel, 1994), suggesting that strains YIM $49065^{\mathrm{T}}$, I. calvum DSM $43043^{\mathrm{T}}$ and H. oryzae DSM $22331^{\mathrm{T}}$ represent different species.

On the basis of phenotypic, genotypic and phylogenetic data presented here, strain YIM $49065^{\mathrm{T}}$ differs from its closest relatives, I. calvum DSM $43043^{\mathrm{T}}$ and H. oryzae DSM $22331^{\mathrm{T}}$. It is suggested that strain YIM $49065^{\mathrm{T}}$ should be recognized as a novel species of the genus Intrasporangium, for which we propose the name Intrasporangium mesophilum sp. nov. Furthermore, based on chemotaxonomic characteristics and phylogenetic analysis, we propose that $H$. oryzae should be reclassified as Intrasporangium oryzae comb. nov. The description of the genus Intrasporangium is emended, and differential chemotaxonomic characteristics among the genera of the family Intrasporangiaceae are listed in Table S2.

\section{Emended description of the genus Intrasporangium Kalakoutskii et al. 1967}

This emended description is based on that given by Stackebrandt \& Schumann (2006), with the following changes and additions. The predominant menaquinone is MK- $8\left(\mathrm{H}_{4}\right)$. Major fatty acids $(>10 \%)$ are iso- $\mathrm{C}_{15: 0}$ and iso$\mathrm{C}_{16: 0}$. The polar lipids comprise diphosphatidylglycerol, phosphatidylglycerol, phosphatidylethanolamine, phosphatidylinositol and phosphatidylinositol mannoside, with an unknown ninhydrin-positive phosphoglycolipid and two unknown lipids. The type species is Intrasporangium calvum.

\section{Emended description of Intrasporangium calvum Kalakoutskii et al. 1967}

The description is based on that by Kalakoutskii et al. (1967) and Stackebrandt \& Schumann (2006) with the following features. Growth is observed in the range $\mathrm{pH} \mathrm{6-8}$ and 20$40{ }^{\circ} \mathrm{C}$. $\mathrm{NaCl}$ tolerance range is $0-3 \%(\mathrm{w} / \mathrm{v})$. Tests for catalase activity and nitrate reduction are positive; tests for $\mathrm{H}_{2} \mathrm{~S}$ production, gelatin liquefaction and urea hydrolysis are negative. Cellobiose, fructose, raffinose, L-rhamnose, sucrose and D-xylose are utilized as sole carbon source, but arabinose, glucose, inositol, lactose, mannitol, D-ribose, sorbose and trehalose are not utilized. The dominant menaquinone, major cellular fatty acids and polar lipid profile are as described in the description for the genus Intrasporangium.

The type strain is ATCC $23552^{\mathrm{T}}\left(=\mathrm{DSM} 43043^{\mathrm{T}}=\mathrm{NBRC}\right.$ $12989^{\mathrm{T}}=\mathrm{JCM} 3097^{\mathrm{T}}=$ NRRL B-3866 ${ }^{\mathrm{T}}=$ VKM Ac-701 ${ }^{\mathrm{T}}$ ).

\section{Description of Intrasporangium oryzae comb. nov.}

Intrasporangium oryzae (o.ry'zae. L. gen. n. oryzae of rice, pertaining to the isolation of the type strain from rice paddy soil).

Basonym: Humihabitans oryzae Kageyama et al. 2007.

The description is identical to that given by Kageyama et al. (2007), supplemented with recent data. Nitrate is reduced, but gelatin is not hydrolysed and $\mathrm{H}_{2} \mathrm{~S}$ is not produced. Can use fructose, glucose, inositol, mannitol, sorbose, sucrose, trehalose and D-xylose as sole carbon sources, but not arabinose, cellobiose, lactose, raffinose, L-rhamnose or D-ribose. The polar lipids remain as given in the genus description.

The type strain is KV- $657^{\mathrm{T}}\left(=\mathrm{JCM} 15924^{\mathrm{T}}=\mathrm{NBRC} 101802^{\mathrm{T}}\right.$ $=$ NRRL B $-24470^{\mathrm{T}}$ ), isolated from rice paddy soil in Japan.

\section{Description of Intrasporangium mesophilum sp. nov.}

Intrasporangium mesophilum [me.so.'phi.lum. Gr. adj. mesos middle; Gr. adj. philos loving; N.L. neut. adj. mesophilum middle (temperature)-loving, mesophilic].

Aerobic, Gram-positive, non-motile actinomycete that forms extensively branched and fragmenting mycelia. Grows well on ISP 2, ISP 3, ISP 5, potato-glucose agar, nutrient agar and Czapek's agar but poorly on ISP 4 . No diffusible pigment is produced. Temperature range for growth is $20-37{ }^{\circ} \mathrm{C}$, with optimum growth at $28{ }^{\circ} \mathrm{C}$. Growth occurs at $\mathrm{pH}$ 6-8 and in the presence of $0-3 \% \mathrm{NaCl}$. Gelatin is degraded, but casein, cellulose, urea and Tweens 20, 40 and 80 are not. Positive for catalase, reduction of nitrate, and milk coagulation and peptonization, but negative for $\mathrm{H}_{2} \mathrm{~S}$ and melanin production. Fructose, glucose, D-ribose, sucrose and D-xylose are utilized as sole carbon sources, but arabinose, cellobiose, inositol, lactose, mannitol, raffinose, L-rhamnose, sorbose and trehalose are not. The cell wall contains LL-diaminopimelic acid as the diagnostic diamino acid. Whole-cell hydrolysates contain galactose, mannose, arabinose and glucose. The predominant menaquinone is MK- $8\left(\mathrm{H}_{4}\right)$. The major fatty acids $(>10 \%)$ are iso- $\mathrm{C}_{14: 0}$, iso- $\mathrm{C}_{15: 0}$ and iso- $\mathrm{C}_{16: 0}$. The polar lipids comprise diphosphatidylglycerol, phosphatidylglycerol, phosphatidylethanolamine, phosphatidylinositol, phosphatidylinositol mannoside, an unknown ninhydrin-positive phosphoglycolipid and two unknown lipids. The DNA $\mathrm{G}+\mathrm{C}$ content of the type strain is $69.6 \mathrm{~mol} \%$. 
The type strain, YIM $49065^{\mathrm{T}}\left(=\mathrm{DSM} 23217^{\mathrm{T}}=\right.$ CCTCC AA $209077^{\mathrm{T}}$ ), was isolated from the rhizospheric soil of an oilseed plant, Jatropha curcas, collected in Chuxiong, Yunnan province, China.

\section{Acknowledgements}

This research was supported by National Basic Research Program of China (no. 2010CB833801), Key Project of International Cooperation (2007DFB31620), Yunnan Provincial Science and Technology Department (2009DA002), Yunnan University (2009C16Q) and National Undergraduate Innovation Experiment Project.

\section{References}

Altschul, S. F., Gish, W., Miller, W., Myers, E. W. \& Lipman, D. J. (1990). Basic local alignment search tool. J Mol Biol 215, 403-410.

Collins, M. D. \& Jones, D. (1980). Lipids in the classification and identification of coryneform bacteria containing peptidoglycan based on 2, 4-diaminobutyric acid. J Appl Bacteriol 48, 459-470.

Collins, M. D., Faulkner, M. \& Keddie, R. M. (1984). Menaquinone composition of some sporeforming actinomycetes. Syst Appl Microbiol 5, 20-29.

Cowan, S. T. \& Steel, K. J. (1965). Manual for the Identification of Medical Bacteria. London: Cambridge University Press.

Dong, X.-Z. \& Cai, M.-Y. (2001). Manual for the Systematic Identification of General Bacteria. Beijing: Science Press. (in Chinese)

Ezaki, T., Hashimoto, Y. \& Yabuuchi, E. (1989). Fluorometric deoxyribonucleic acid-deoxyribonucleic acid hybridization in microdilution wells as an alternative to membrane filter hybridization in which radioisotopes are used to determine genetic relatedness among bacterial strains. Int J Syst Bacteriol 39, 224-229.

Felsenstein, J. (1985). Confidence limits on phylogenies: an approach using the bootstrap. Evolution 39, 783-791.

Fitch, W. M. (1971). Toward defining the course of evolution: minimum change for a specific tree topology. Syst Zool 20, 406-416.

Gordon, R. E., Barnett, D. A., Handerhan, J. E. \& Pang, C. H.-N. (1974). Nocardia coeliaca, Nocardia autotrophica, and the nocardin strain. Int J Syst Bacteriol 24, 54-63.

Gregersen, T. (1978). Rapid method for distinction of Gram-negative from Gram-positive bacteria. Eur J Appl Microbiol Biotechnol 5, 123127.

Guindon, S. \& Gascuel, O. (2003). A simple, fast, and accurate algorithm to estimate large phylogenies by maximum likelihood. Syst Biol 52, 696-704.

Hasegawa, T., Takizawa, M. \& Tanida, S. (1983). A rapid analysis for chemical grouping aerobic actinomycetes. J Gen Appl Microbiol 29, 319-322.

He, L., Li, W., Huang, Y., Wang, L., Liu, Z., Lanoot, B., Vancanneyt, M. \& Swings, J. (2005). Streptomyces jietaisiensis sp. nov., isolated from soil in northern China. Int J Syst Evol Microbiol 55, 1939-1944.

Kageyama, A., Takahashi, Y. \& Ōmura, S. (2007). Humihabitans oryzae gen. nov., sp. nov. Int J Syst Evol Microbiol 57, 2163-2166.

Kalakoutskii, L. V. (1989). Genus Intrasporangium Kalakoutskii, Kirillova and Krasil'nikov 1967, $7^{\mathrm{AL}}$. In Bergey's Manual of Systematic Bacteriology, vol. 4, pp. 2395-2397. Edited by S. T. Williams, M. E. Sharpe \& J. G. Holt. Baltimore, MD: Williams and Wilkins.
Kalakoutskii, L. V., Kiprillove, I. P. \& Krassilnikov, N. A. (1967). A new genus of the Actinomycetales, Intrasporangium gen. nov. J Gen Microbiol 48, 79-85.

Kroppenstedt, R. M. (1982). Separation of bacterial menaquinones by HPLC using reverse phase (RP18) and a silver loaded ion exchanger as stationary phases. J Liq Chromatogr 5, 2359-2367.

Li, W.-J., Xu, P., Schumann, P., Zhang, Y.-Q., Pukall, R., Xu, L.-H., Stackebrandt, E. \& Jiang, C.-L. (2007). Georgenia ruanii sp. nov., a novel actinobacterium isolated from forest soil in Yunnan (China), and emended description of the genus Georgenia. Int J Syst Evol Microbiol 57, 1424-1428.

Marmur, J. (1961). A procedure for the isolation of deoxyribonucleic acid from microorganisms. J Mol Biol 3, 208-218.

Mesbah, M., Premachandran, U. \& Whitman, W. B. (1989). Precise measurement of the $\mathrm{G}+\mathrm{C}$ content of deoxyribonucleic acid by high performance liquid chromatography. Int J Syst Bacteriol 39, 159-167.

Minnikin, D. E., Collins, M. D. \& Goodfellow, M. (1979). Fatty acid and polar lipid composition in the classification of Cellulomonas, Oerskovia and related taxa. J Appl Bacteriol 47, 87-95.

Minnikin, D. E., O’Donnell, A. G., Goodfellow, M., Alderson, G., Athalye, M., Schaal, A. \& Parlett, J. H. (1984). An integrated procedure for the extraction of bacterial isoprenoid quinones and polar lipids. J Microbiol Methods 2, 233-241.

Pridham, T. G. \& Gottlieb, D. (1948). The utilization of carbon compounds by some actinomycetales as an aid for species determination. J Bacteriol 56, 107-114.

Saitou, N. \& Nei, M. (1987). The neighbor-joining method: a new method for reconstructing phylogenetic trees. Mol Biol Evol 4, 406-425.

Shirling, E. B. \& Gottlieb, D. (1966). Methods for characterization of Streptomyces species. Int J Syst Bacteriol 16, 313-340.

Stackebrandt, E. \& Goebel, B. M. (1994). Taxonomic note: a place for DNA-DNA reassociation and $16 \mathrm{~S}$ rRNA sequence analysis in the present species definition in bacteriology. Int J Syst Bacteriol 44, 846-849.

Stackebrandt, E. \& Schumann, P. (2006). Introduction to the taxonomy of actinobacteria. In The Prokaryotes: a Handbook on the Biology of Bacteria, 3rd edn, vol. 3, pp. 297-321. Edited by M. Dworkin, S. Falkow, E. Rosenberg, K.-H. Schleifer \& E. Stackebrandt. New York: Springer.

Stackebrandt, E., Rainey, F. A. \& Ward-Rainey, N. L. (1997). Proposal for a new hierarchic classification system, Actinobacteria classis nov. Int J Syst Bacteriol 47, 479-491.

Tamura, K., Dudley, J., Nei, M. \& Kumar, S. (2007). MEGA4: molecular evolutionary genetics analysis (MEGA) software version 4.0. Mol Biol Evol 24, 1596-1599.

Tang, S.-K., Wang, Y., Chen, Y., Lou, K., Cao, L.-L., Xu, L.-H. \& Li, W.-J. (2009). Zhihengliuella alba sp. nov., and emended description of the genus Zhihengliuella. Int J Syst Evol Microbiol 59, 2025-2032.

Thompson, J. D., Gibson, T. J., Plewniak, F., Jeanmougin, F. \& Higgins, D. G. (1997). The CLUSTAL_X windows interface: flexible strategies for multiple sequence alignment aided by quality analysis tools. Nucleic Acids Res 25, 4876-4882.

Wang, Z.-G., Wang, Y.-X., Liu, J.-H., Chen, Y.-G., Zhang, X.-X., Wen, M.-L., Xu, L.-H., Peng, Q. \& Cui, X. L. (2009). Fodinibacter luteus gen. nov., sp. nov., an actinobacterium isolated from a salt mine. Int J Syst Evol Microbiol 59, 2185-2190.

Zhi, X.-Y., Li, W.-J. \& Stackebrandt, E. (2009). An update of the structure and 16S rRNA gene sequence-based definition of higher ranks of the class Actinobacteria, with the proposal of two new suborders and four new families and emended descriptions of the existing higher taxa. Int J Syst Evol Microbiol 59, 589-608. 